\title{
PENGARUH KEPEMILIKAN HANDPHONE TERHADAP UANG SAKU PESERTA DIDIK UNTUK PEMBELIAN PULSA PAKET INTERNET DI SMK YAMAS JAKARTA
}

\author{
Windi Megayanti dan Nicky Rosadi \\ Dosen Progran Studi Pendidikan Ekonomi Universitas Indraprasta PGRI \\ $\underline{\text { megayantiwindi@gmail.com, nicky.rosadi@unindra.ac.id }}$
}

\begin{abstract}
Abstrak
Penelitian ini bertujuan untuk mengetahui pengaruh intensitas penggunaan handphone untuk mengakses internet terhadap peningkatan prestasi belajar peserta didik SMK Yamas Jakarta. Selain itu juga untuk mengetahui ada/tidaknya pengaruh kepemilikan handphone terhadap uang saku peserta didik untuk pembelian pulsa paket internet di SMK Yamas Jakarta. Metode yang digunakan dalam penelitian ini ialah metode deskriptif dan asosiatif, dengan maksud di mana metode tersebut mendeskripsikan atau menggambarkan fenomena yang diselidiki dan membuktikannya dengan uji koefisien korelasi, analisis regresi, koefisien determinan dan uji hipotesis. Populasi dalam penelitian ini adalah seluruh peserta didik kelas X dan XI di Sekolah Menengah Kejuruan (SMK) Yamas Jakarta Timur dengan sampel sebanyak 53 anak peserta didik. Untuk memperoleh data yang lebih akurat, instrumen yang digunakan peneliti adalah angket/kuesioner. Kuesioner dalam penelitian ini digunakan untuk menyaring data variabel $\mathrm{X}$ (kepemilikan handphone) sedangkan variabel Y (uang saku peserta didik) yang didapat dari angket yang disebar pada peserta didik yang bersangkutan.

Kata kunci: handphone, internet, uang saku, pembelian pulsa paket internet
\end{abstract}

\section{PENDAHULUAN}

Perkembangan masyarakat dunia pada umumnya dan masyarakat Indonesia pada khususnya seolah tidak terbendung lagi dengan adanya kemajuan teknologi di era globalisasi saat ini. Tahapan ini merupakan kelanjutan dari masyarakat modern. Dalam artian masyarakat yang kehidupannya dekat dengan segala perkembangan teknologi yang sekarang berimbas pada perubahan cara berpikir masyarakat di segala bidang termasuk ke dalam pendidikan. Masyarakat informasi merupakan kelanjutan dari masyarakat modern. Pada masyarakat informasi, media elektronik sangat memegang peranan penting, bahkan menentukan corak kehidupan. Adanya kemajuan di bidang informasi, terkait penggunaan media elektronik, akan berpengaruh pada kejiwaan dan kepribadian masyarakat.

Perkembangan teknologi informasi dan komunikasi sudah sedemikian cepat sehingga tanpa kita sadari telah mempengaruhi setiap aspek kehidupan manusia. Dewasa ini produk teknologi sudah menjadi kebutuhan sehari-hari dalam menjalankan aktivitas kehidupan. Penggunaan televisi, telepon, telepon 
genggam (handphone), dan internet bukan lagi menjadi hal yang baru, khususnya di kota-kota besar.

Telepon seluler atau telepon genggam (handphone) saat ini sudah menjadi bagian dari gaya hidup masyarakat modern. Di mana hampir setiap orang, termasuk pelajar menggunakan handphone untuk mempermudah melakukan komunikasi serta mendapatkan informasi. Telepon seluler adalah perangkat telekomunikasi elektronik yang mempunyai kemampuan dasar dengan telepon fixed line konvensional, tetapi dapat dibawa ke mana-mana dan tidak perlu disambungkan dengan jaringan telepon menggunakan kabel (nirkabel, wireless).

Sekarang ini kepemilikan handphone tidak hanya didasarkan pada fungsi utama handphone, yakni sebagai alat komunikasi, tetapi kelengkapan fitur-fitur serta desain produk juga menjadi dasar pertimbangan konsumen dalam memilih jenis atau merek handphone yang akan digunakan. Handphone saat ini tidak hanya berfungsi sebagai alat komunikasi verbal saja, tetapi juga sebagai alat pengambil gambar, pemutar musik, games, penyimpan data, bahkan untuk mencari informasi yang bersumber dari internet.

Internet (International Network) merupakan jaringan komputer terluas di dunia $w w w$ (world wide web) di mana antara satu komputer dengan komputer yang lainnya saling berhubungan dan saling berkomunikasi. Menurut Kadir (dalam Uno dan Lamatenggo, 2010:104) "Internet merupakan jaringan komputer". Jaringan komputer ini menghubungkan jutaan komputer yang tersebar di seluruh dunia. Di samping itu, menurut Williams (dalam Uno dan Lamatenggo, 2010:104) mengatakan bahwa "Internet adalah kumpulan jaringan komputer sehingga pemakai dapat berbagi informasi dengan sumber-sumber yang lebih luas."

Keberadaan handphone pada saat ini tidak hanya digunakan oleh kalangan dewasa saja. Sekarang, anak-anak pun banyak yang memiliki handphone dengan kecanggihan yang tidak kalah dengan handphone orang dewasa. Dampaknya, banyak orang menjadi autis (dalam arti sibuk dengan handphone-nya masing-masing). Hal ini terutama dipengaruhi adanya jejaring sosial seperti Facebook, Twitter, Instagram, YouTube, dan lain-lain, yang sudah menjadi bagian hidup dari generasi milenial (sebutan untuk mereka yang 
hidupnya tidak bisa dipisahkan dari handphone). Fenomena semacam inilah yang kemudian mengubah persepsi masyarakat bahwa kepemilikan handphone tidak hanya masalah kebutuhan namun juga terkait gaya hidup.

Remaja saat ini khususnya siswa SMK Yamas Jakarta sedang menggemari mengakses internet melalui handphone yang mereka miliki di antaranya mencari informasi tentang pelajaran, hobi mereka, tokoh yang mereka senangi, mengobrol lewat fasilitas chatting seperti WhatsApp, Line, dll. bahkan update status dan mengunggah foto mereka di jejaring sosial seperti Facebook, Twitter, dan Instagram. Remaja seperti mereka yang berumur sekitar 15-18 tahun memang masih dalam kondisi labil dan memiliki rasa ingin tahu yang tinggi. Itu sebabnya, hal-hal yang baru bagi mereka, akan mereka cari referensinya melalui internet, atau yang biasa mereka sebut googling (pencarian informasi melalui Google).

Untuk dapat mengakses internet ini, tentu saja para remaja memerlukan kuota dan kualitas layanan yang baik. Provider telepon seluler pun berlombalomba menarik konsumen dengan "janji” kuota termurah dan layanan terbaik. Perang tarif operator telepon seluler pun tak terhindarkan. Konsumen semakin leluasa memilih provider terbaik mereka.

Pelajar SMK Yamas, misalnya, sampai rela menyisihkan uang saku mereka untuk membeli pulsa paket internet, hanya demi eksis di dunia maya. Uang saku yang seharusnya digunakan untuk membeli makan, kini beralih penggunaan untuk "kepentingan lain". Akibatnya, orang tua, secara tidak langsung, terpaksa memberikan uang saku lebih agar alokasi untuk pembelian pulsa paket internet dapat terpenuhi. Sayangnya, tidak semua orang tua memberikan uang saku lebih kepada anaknya yang memiliki kebutuhan untuk membeli pulsa paket internet itu. Hal ini kemudian berimbas pada fungsi uang saku yang seyogianya digunakan untuk membeli jajanan. Kini, mereka harus menahan diri tidak jajan agar uang saku yang mereka miliki cukup untuk membeli pulsa paket internet di handphone mereka.

Berdasarkan uraian di atas maka akan diteliti pengaruh kepemilikan handphone terhadap uang saku peserta didik untuk pembelian pulsa paket internet di SMK Yamas Jakarta. Adapun tujuan yang ingin dicapai dalam penelitian ini adalah mengetahui pengaruh intensitas penggunaan handphone untuk mengakses 
internet terhadap peningkatan prestasi belajar peserta didik SMK Yamas Jakarta. Selain itu juga untuk mengetahui pengaruh kepemilikan handphone terhadap uang saku peserta didik untuk pembelian pulsa paket internet di SMK Yamas Jakarta.

\section{KAJIAN PUSTAKA}

\section{Teknologi Komunikasi}

Seiring dengan perkembangan zaman, teori komunikasi hingga kini terus berkembang. Straubhaar dalam M. Mufid (2005:15) mengatakan "Komunikasi kekinian adalah komunikasi yang termediasi oleh teknologi dalam berbagai bentuk jenis media baru. Media baru tersebut adalah media masa yang mengalami perubahan konsep secara cepat seiring dengan percepatan teknologi komputer, internet, dan telekomunikasi digital".

Menurut M. Mufid (2005:33) terdapat beberapa jenis teknologi komunikasi antara lain:

a. Radio

Radio dimulai dari penemuan phonograph (gramofon), yang juga bisa digunakan memainkan rekaman. Radio adalah wahana komunikasi yang disalurkan lewat gelombang radio.

b. Televisi

Televisi pertama kali ditemukan oleh Philo Farnsworth. Televisi adalah serangkaian gambar elektronik yang bisa digunakan sebagai media massa. Televisi pertama di Indonesia adalah TVRI dan mulai mengudara tanggal 24 Agustus 1962.

c. Telepon

Karena jaringannya yang menggunakan kabel dan instalasi, sehingga alat ini hanya bisa berada di satu tempat yaitu di rumah atau di kantor-kantor dan tempat umum lainnya.

\section{d. Handphone}

Handphone sebuah produk teknologi yang di zaman ini hampir semua orang memilikinya. Pembawaannya yang praktis dan harga yang relatif terjangkau, serta kebutuhan akan informasi yang sangat dibutuhkan, penggunaannya juga mudah dipelajari, membuat alat ini digandrungi masyarakat. 


\section{e. Internet}

Berbeda dengan teknologi yang tersebut di atas, internet dapat diakses melalui berbagai perangkat keras, seperti komputer, handphone, dan teknologi canggih lainnya, yang terpenting ada jaringan dan fasilitas internetnya. Tak kalah dengan handphone, internet juga digandrungi oleh masyarakat saat ini, terlebih karena banyak media sosial yang berkembang seperti Facebook dan Twitter.

\section{Handphone}

Kehadiran handphone yang membanjiri kota-kota di Indonesia telah membentuk aktivitas komunikasi tersendiri. Dengan kata lain, revolusi dalam berkomunikasi di Indonesia sudah memasuki tahap baru dengan kehadiran handphone. Handphone tidak hanya untuk menerima dan menelepon serta mengirim SMS, tetapi bisa juga digunakan untuk mengakses internet.

Perkembangan jenis handphone semakin hari semakin meningkat. Mulai dari fasilitas yang disediakan, sampai bentuknya. Bentuknya ada yang besar sampai yang sangat kecil dan tipis, tetapi semua itu mempunyai fungsi yang sama, hanya fasilitasnya berbeda. Perkembangan yang semakin meningkat itu juga berkaitan dengan jumlah pemakai kartu untuk mengoperasionalkan handphone, baik yang prabayar maupun pascabayar. Di Indonesia ada beberapa provider di antaranya adalah SimPATI dan Kartu Halo (Telkomsel), Mentari dan IM3 (Indosat), 3, juga Axis dan XL.

Akan arti pentingnya ponsel, perlu disimak apa yang dilakukan oleh Siemens Mobile Phone Indonesia. Dalam sebuah survei yang berjudul Survey Siemens Mobile Lifestyle didapatkan informasi menarik bagaimana mobile phone dapat menjadi bagian hidup dan napas manusia sehari-hari. Sekitar $79 \%$ penduduk Indonesia merasa sangat kehilangan ketika handphone mereka tidak ada di sekitarnya. Sementara 62\% akan segera tidak sadar memeriksa handphone mereka ketika mendengar nada dering handphone mereka daripada membaca buku (Kompas, 17 April 2003). 


\section{Uang Saku dan Uang Jajan}

Menurut Triarti dalam Mufti (2012:102) "Uang saku seharusnya tidak disamakan dengan uang jajan”. Tujuan pemberian uang saku kepada anak bukanlah untuk jajan melainkan agar anak dapat menabung dan mengelola uangnya sendiri.

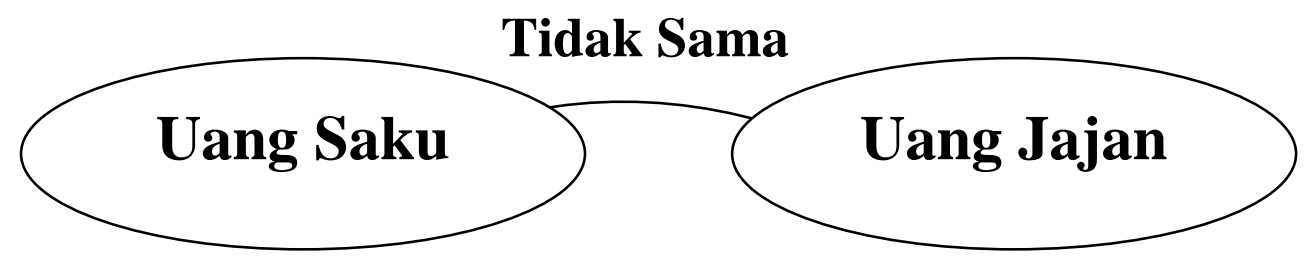

Gambar 1. Perbedaan Uang Saku dan Uang Jajan

Sumber: Triatri dalam Mufti (2012:103)

Fungsi pemberian uang saku, selain belajar mengenai nilai nominal secara sederhana dan fungsi uang, anak pun harus diajari bahwa apabila membutuhkan dan menginginkan sesuatu perlu ada usaha dan untuk berbelanja juga harus ada rencana. Menurut psikolog Sri Triarti dalam Mufti (2012:101) "Sangat penting memberikan uang saku terhadap anak, mengingat pendidikan tentang usaha perlu diketahui anak agar ia mengerti bahwa semua orang memiliki uang yang terbatas". Menurut Sri, kasihan juga kalau anak tak pernah jajan, apalagi kalau ia melihat temannya banyak yang jajan.

Mengajarkan anak bagaimana mengelola atau me-manage uang memang susah-susah gampang. Untuk anak yang belum atau kurang mendapatkan pendidikan mengatur keuangan, menurut Nathan dalam Mufti (2012:101) menawarkan teori terbaru kreasinya yang cukup simpel. Pendiri Share Save Spend, sebuah organisasi yang membantu anak muda dan dewasa untuk memiliki kebiasaan manajemen uang yang baik, menuangkan idenya dalam buku Prodigal Sons and Material Girls: How Not to Be Your Child's ATM, yang mencerahkan semua orang untuk bisa belajar menyeimbangkan antara pengeluaran dan menabung.

Menurut Nathan dalam Mufti (2012:102) "Uang jajan layak diberikan kepada anak sejak umur lima tahun. Sejak itulah anak harus diajarkan untuk bisa menabung dari uang jajannya, dan membaginya untuk kepentingan keluarga atau 
sebagai aksi sosial". Sisa dari uang jajan itulah anak belanjakan. Nathan menambahkan sebuah trik khusus, terkait permintaan mendadak anak terhadap sesuatu yang dilihatnya saat menemani orang tuanya berbelanja. Sebelum hal semacam itu terjadi, orang tua harus membiasakan membuat peraturan agar mereka memikirkan segala keinginan yang diminta sebelumnya.

\section{Peserta Didik}

Peserta didik adalah salah satu komponen wajib dari komponenkomponen pendidikan yang mana jika salah satu komponen ini tidak ada maka proses belajar mengajar tidak akan berlangsung. Peserta didik adalah objek yang menjadi tujuan pendidikan. Peserta didik merupakan "raw material" (bahan mentah) di dalam transformasi yang disebut pendidikan. Menurut Tirtarahardja (2005:52) "Peserta didik adalah subjek atau pribadi yang otonom, yang ingin diakui keberadaannya".

Menurut pasal 1 ayat 4 UU RI No. 20 Tahun 2003 tentang Sistem Pendidikan Nasional, peserta didik adalah anggota masyarakat yang berusaha mengembangkan dirinya melalui proses pendidikan pada jalur jenjang dan jenis pendidikan tertentu.

Tirtarahardja (2005:52) ciri khas peserta didik yang perlu dipahami adalah:

a. Peserta didik adalah individu yang memiliki potensi fisik dan psikis yang khas, sehingga merupakan insan yang unik.

b. Peserta didik merupakan individu yang sedang berkembang.

c. Peserta didik adalah individu yang membutuhkan bimbingan individual dan perlakuan manusiawi.

d. Peserta didik merupakan individu yang memiliki kemampuan untuk mandiri.

\section{Sikap Konsumen}

Sikap konsumen adalah faktor penting yang akan mempengaruhi konsumen. Konsep sikap sangat terkait dengan kepercayaan dan perilaku. Sikap merupakan ungkapan perasaan konsumen tentang suatu obyek apakah disukai atau tidak. Paul and Olson dalam Agustina (2011:53) menyatakan:

a. Sikap adalah evaluasi konsep secara menyeluruh yang dilakukan oleh seseorang. 
b. Evaluasi adalah tanggapan pada tingkat intensitas dan gerakan yang relatif rendah.

c. Evaluasi diciptakan oleh sistem afektif (emosi, perasaan, suasana hati), kognitif (dibentuk ketika konsumen mengintegrasikan pengetahuan, arti atau kepercayaan tentang konsep sikap) serta konatif (kecenderungan melakukan sesuatu terhadap obyek sikap).

Contoh: Konsumen yakin bahwa jeruk dapat mencegah sariwan (termasuk aspek kognitif), konsumen tersebut sangat suka makan jeruk (termasuk aspek afektif), dan konsumen tersebut akan membeli jeruk (termasuk aspek konatif).

Penjelasan di atas merupakan teori lama dari pandangan tradisional. Ada teori baru yang menyatakan bahwa sikap memiliki sifat multiatribut/multidimensi. Menurut Fisbein (dalam Agustina, 2011:53) bahwa penilaian atribut dilihat dari:

a. Belief/keyakinan

Jumlah keyakinan/kepercayaan utama tentang obyek sikap nilainya cenderung tidak lebih dari 7 atau 9, karena keterbatasan kapasitas konsumen dalam menerjemahkan dan mengintegrasikan informasi.

b. Evaluasi terhadap atribut

Mencerminkan seberapa baik konsumen menilai suatu atribut. Faktorfaktor yang mempengaruhi pembentukan sikap antara lain:

1) Pengalaman pribadi

2) Pengaruh keluarga dan teman-teman

3) Direct marketing

4) Media masa

\section{Perilaku Konsumen}

Perilaku konsumen sebagai perilaku yang diperlihatkan konsumen dalam mencari, membeli, menggunakan, mengevaluasi, dan menghabiskan produk dan jasa yang diharapkan akan memuaskan kebutuhan.

Menurut Kotler (2007: 214-232), "Perilaku pembelian konsumen dipengaruhi oleh faktor-faktor budaya, sosial, pribadi, dan psikologis."

a. Faktor Budaya

Budaya, sub-budaya, dan kelas sosial sangat penting bagi perilaku pembelian. Budaya merupakan penentu keinginan dan perilaku yang paling 
dasar. Anak-anak yang sedang bertumbuh mendapatkan seperangkat nilai, persepsi, preferensi, dan perilaku dari keluarga dan lembaga-lembaga lainnya.

b. Faktor Sosial

Selain faktor budaya, perilaku konsumen dipengaruhi oleh faktorfaktor sosial seperti kelompok acuan, keluarga, peran dan status sosial. Kelompok acuan seseorang terdiri dari semua kelompok yang memiliki pengaruh langsung (tatap muka) atau tidak langsung terhadap sikap atau perilaku orang tersebut. Keluarga merupakan organisasi pembelian konsumen yang paling penting dalam masyarakat dan para anggota keluarga menjadi kelompok acuan primer yang paling berpengaruh. Peran meliputi kegiatan yang diharapkan akan dilakukan oleh seseorang, masing-masing peran menghasilkan status.

c. Faktor Pribadi

Karakteristik faktor pribadi meliputi usia dan tahap dalam siklus hidup, pekerjaan dan lingkungan ekonomi, kepribadian dan konsep diri, serta nilai dan gaya hidup pembeli.

d. Faktor Psikologis

Satu perangkat proses psikologis berkombinasi dengan karakteristik konsumen tertentu untuk menghasilkan proses keputusan dan keputusan pembelian. Empat proses psikologis antara lain motivasi, persepsi, pembelajaran, dan memori secara fundamental mempengaruhi tanggapan konsumen terhadap berbagi rangsangan pemasaran.

Menurut Agustina (2011:57) ada beberapa cara mengukur perilaku konsumen antara lain:

a. Pernyataan sendiri (self-report)

Yaitu suatu cara di mana orang-orang yang ditanyai secara langsung tentang kepercayaan atau perasaan terhadap suatu obyek.

b. Pengamatan perilaku (observation of overt behavior)

Perilaku yang dimaksud adalah tindakan-tindakan yang dapat diamati.

c. Teknik tidak langsung (indirect techniques)

Metode ini tidak menanyakan perilaku secara langsung, yang ditanya adalah hal-hal lain, namun dari data yang diperoleh, peneliti dapat menyimpulkan perilaku konsumen tersebut. Komponen perilaku yang bisa 
ditelusuri adalah sikap, persepsi, preferensi, brand image, loyalitas, kepuasan, keterlibatan dan tipe perilaku konsumen. Metode yang digunakan: multiatribut, uji asosiasi,uji melengkapi kalimat, uji bercerita.

\section{d. Performance of objective task}

Metode ini didasari oleh anggapan bahwa seseorang akan mengingat fakta-fakta yang mendukung sikapnya terhadap suatu obyek.

e. Reaksi psikologis

Memerlukan peralatan laboratorium untuk mengukur kondisi psikologis seseorang melalui tekanan saraf, denyut jantung, gelombang listrik tubuh, dan lain-lain.

\section{Proses Pengambilan Keputusan Membeli}

Proses psikologis dasar ini memainkan peran penting dalam memahami bagaimana konsumen secara aktual mengambil keputusan pembelian. Para pemasar harus memahami setiap sisi perilaku konsumen.

Seorang konsumen yang hendak melakukan pilihan maka harus menentukan alternatif pilihan. Keputusan konsumen melewati lima tahapan yaitu pengenalan kebutuhan, pencarian informasi, evaluasi alternatif, keputusan pembelian, dan perilaku pasca pembelian.

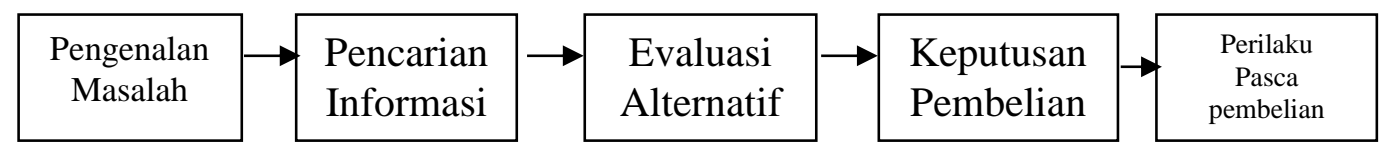

Gambar 2. Proses Pengambilan Keputusan Membeli

Sumber: (Kottler \& Keller, 2007:235)

Proses pertama pengambilan keputusan adalah pengenalan masalah. Proses pembelian dimulai ketika pembeli mengenali masalah atau kebutuhan. Kebutuhan tersebut dapat dicetuskan dari rancangan internal atau eksternal.

Tahap kedua adalah pencarian informasi yaitu suatu kegiatan termotivasi dari pengetahuan yang tersimpan di dalam ingatan konsumen dan pengumpulan informasi dari pasar. Pencarian informasi untuk melihat pengetahuan yang relevan dengan keputusan yang tersimpan dalam ingatan jangka panjang disebut pencarian internal. Jika pencarian internal memadai maka pencarian eksternal 
tidak diperlukan untuk mencari informasi tambahan dari lingkungan. Pada tahap ini perhatian utama pemasar adalah sumber informasi utama yang akan dicari konsumen.

Sumber-sumber pengenalan informasi konsumen dapat dikelompokkan menjadi empat (Kottler \& Keller, 2007:235), yaitu:

a. Sumber pribadi: keluarga, teman, tetangga, kenalan.

b. Sumber komersial: iklan, wiraniaga, penyalur, kemasan.

c. Sumber umum: media massa, organisasi penilai konsumen.

d. Sumber pengalaman: penanganan, pemeriksaan, penggunaan produk.

Tahap ketiga adalah evaluasi alternatif yaitu kegiatan konsumen dalam mengevaluasi berbagai alternatif dan membuat pertimbangan nilai terbaik untuk memenuhi kebutuhan. Beberapa hal yang perlu diketahui dalam proses evaluasi alternatif adalah konsumen berusaha memenuhi kebutuhan, konsumen mencari manfaat tertentu dari solusi produk, konsumen memandang masing-masing produk sebagai sekumpulan atribut dengan kemampuan yang berbeda-beda dalam memberikan manfaat yang digunakan untuk memuaskan kebutuhan.

Tahap keempat adalah keputusan pembelian adalah dalam melaksanakan pembelian, konsumen bisa mengambil lima sub-keputusan yaitu merek, dealer, kuantitas, waktu dan metode pembayaran. Dalam pembelian produk sehari-hari, keputusannya lebih kecil dan kebebasannya juga lebih kecil.

Tahap kelima adalah tahap perilaku pasca pembelian yaitu tahap yang dilakukan setelah konsumen melakukan pembelian. Setelah melakukan pembelian, maka konsumen akan mengevaluasi hasil pembelian yang dilakukannya. Hasil evaluasi pasca-pembelian dapat berupa kepuasan atau ketidakpuasan. Kepuasan dan ketidakpuasan konsumen merupakan perbandingan antara harapan konsumen sebelum pembelian dengan yang sesungguhnya diperoleh konsumen dari produk yang dibelinya. Kepuasan akan mendorong konsumen membeli dan mengonsumsi ulang produk tersebut. Sedangkan perasaan tidak puas akan menyebabkan konsumen kecewa dan menghentikan pembelian dan konsumsi terhadap produk tersebut.

\section{Kepuasan Konsumen}


Juran (dalam Daryanto, 2014: 90) menyatak bahwa, "Kepuasan konsumen adalah keadaan yang dicapai apabila produk sesuai dengan kebutuhan atau harapan konsumen dan bebas dari kekurangan". Kepuasan konsumen dapat didefinisikan juga sebagai suatu keadaan di mana kebutuhan, keinginan, dan harapan pelanggan dapat terpenuhi melalui produk yang dikonsumsi.

Persepsi konsumen terhadap jasa yang diterimanya menurut Megawati (2006:10) dipengaruhi oleh:

a. Cara Penyampaian Jasa (Service Encounters)

Setiap peristiwa dalam penyampaian jasa, sering kali secara potensial dapat menjadi hal kritis dalam menjamin kepuasan dan loyalitas konsumen. Ketika seorang pelanggan telah mempunyai banyak interaksi dengan perusahaan, setiap penyampaian jasa sangat penting dalam membentuk citra gabungan (kumulatif/menyeluruh) akan perusahaan dalam ingatan konsumen. Setiap pengalaman positif akan menambah citra gabungan terhadap mutu yang tinggi, sementara interaksi negatif akan membuat konsumen merasa ragu atau tidak pasti akan kualitas perusahaan.

b. Bukti Pelayanan (Evidence of Service)

Ada tiga kategori bukti pelayanan, yaitu yang berhubungan dengan orang (people evidence), misalnya keramahan, pengetahuan dan kesabaran karyawan; bukti proses (process evidence), misalnya kemampuan perusahaan menyelenggarakan jasa sesuai dengan janjinya; dan bukti fisik (physical evidence), misalnya kebersihan dan kenyamanan tempat pelayanan.

c. Image Perusahaan

Image perusahaan adalah persepsi tentang suatu organisasi yang ada dalam ingatan konsumen dan dibangun konsumen melalui komunikasi, misalnya iklan, humas, citra fisik, komunikasi dari mulut ke mulut, dan oleh pengalaman nyata terhadap perusahaan. Image positif akan meredam kekecewaan atas pelayanan yang buruk, sedangkan image negatif akan menyebabkan konsumen cepat marah dan tidak puas apabila terjadi pengalaman buruk dan perlu banyak pengalaman baik untuk mengubah keseluruhan image buruk tersebut.

d. Harga 
Harga jasa banyak mempengaruhi persepsi, kualitas, kepuasan, dan nilai jasa. Karena jasa tidak berwujud dan sering sulit dinilai sebelum terjadinya pembelian, maka harga sering kali dikaitkan sebagai indikator pendukung yang mempengaruhi harapan dan persepsi jasa. Pada harga yang tinggi, konsumen akan menuntut kualitas yang tinggi dan persepsi mereka akan mempengaruhi ekspektasinya, sebaliknya bila harga rendah, konsumen akan meragukan kemampuan perusahaan untuk menyampaikan jasa.

\section{METODE}

Pada penelitian ini penulis menggunakan metode deskriptif dan asosiatif, dengan maksud di mana metode tersebut mendeskripsikan atau menggambarkan fenomena yang diselidiki dan membuktikannya dengan uji koefisien korelasi, analisis regresi, koefisien determinan dan uji hipotesis.

Populasi dalam penelitian ini adalah seluruh peserta didik kelas X dan XI di Sekolah Menengah Kejuruan (SMK) Yamas Jakarta Timur sebanyak 53 anak peserta didik. Untuk memperoleh data yang lebih akurat, instrumen yang digunakan peneliti adalah angket/kuesioner. Kuesioner dalam penelitian ini digunakan untuk menyaring data variabel X (kepemilikan handphone) sedangkan variabel Y (uang saku peserta didik) yang didapat dari angket yang disebar pada peserta didik yang bersangkutan. Instrumen penelitian menguraikan variabel $\mathrm{X}$ sebagai variabel bebas, yaitu kepemilikan handphone dan variabel terikat Y, yaitu uang saku peserta didik untuk membeli paket internet pada siswa di SMK Yamas Jakarta tahun 2014.

Data yang digunakan penulis dalam skripsi ini adalah data kuantitatif. Data kuantitatif adalah data berbentuk angka, termasuk dalam kualifikasi ini adalah data yang berskala ukur interval dan rasio. Dalam penelitian ini digunakan koefisien korelasi, regresi, koefisien determinasi dan uji hipotesis (uji t).

\section{HASIL DAN PEMBAHASAN}

Jumlah responden yang dijadikan sumber data di dalam penelitian ini yaitu 53 orang responden yang terdiri atas 21 laki-laki dan 32 perempuan. Dari jumlah itu, diketahui sebanyak 6 responden berusia 15 tahun, 27 responden berusia 16 tahun, 16 responden berusia 17 tahun, dan 4 responden berusia 18 tahun. Adapun kuesioner yang diajukan kepada responden berisi 30 pernyataan, di mana 15 
pernyataan mengenai kepemilikan handphone (variabel $\mathrm{X}$ ) dan 15 pernyataan mengenai uang saku peserta didik (variabel Y).

Berikut hasil yang didapatkan:

Tabel 1. Pernyataan Mengenai Kepemilikan Handphone

\begin{tabular}{|c|c|c|c|c|c|c|}
\hline No & Pernyataan & SS & $\mathrm{S}$ & RR & TS & STS \\
\hline 1 & $\begin{array}{l}\text { Saya memiliki handphone yang bisa } \\
\text { mengakses internet dengan mudah. }\end{array}$ & 29 & 21 & 1 & 2 & 0 \\
\hline 2 & $\begin{array}{l}\text { Tipe handphone saya adalah Android } \\
\text { atau Blackberrry. }\end{array}$ & 18 & 20 & 0 & 9 & 6 \\
\hline 3 & $\begin{array}{l}\text { Saya suka menggunakan handphone } \\
\text { untuk surfing dibandingkan dengan } \\
\text { menggunakan komputer. }\end{array}$ & 16 & 21 & 7 & 8 & 1 \\
\hline 4 & $\begin{array}{l}\text { Saya memiliki handphone lebih dari } \\
\text { satu. }\end{array}$ & 8 & 6 & 3 & 25 & 11 \\
\hline 5 & $\begin{array}{l}\text { Saya membedakan satu handphone } \\
\text { untuk koneksi internet dan yang satunya } \\
\text { untuk komunikasi telepon dan SMS. }\end{array}$ & 9 & 11 & 4 & 17 & 12 \\
\hline 6 & $\begin{array}{l}\text { Dengan adanya internet di handphone, } \\
\text { memudahkan saya dalam menambah } \\
\text { wawasan belajar. }\end{array}$ & 28 & 24 & 1 & 0 & 0 \\
\hline 7 & $\begin{array}{l}\text { Saya sering mencari informasi tentang } \\
\text { pelajaran dibandingkan dengan main } \\
\text { game di handphone. }\end{array}$ & 22 & 20 & 11 & 0 & 0 \\
\hline 8 & $\begin{array}{l}\text { Saya sering telepon, SMS, dan bermain } \\
\text { game di handphone dibandingkan } \\
\text { belajar. }\end{array}$ & 3 & 13 & 11 & 18 & 8 \\
\hline 9 & $\begin{array}{l}\text { Dengan handphone saya bisa update } \\
\text { status di Twitter dan Facebook. }\end{array}$ & 22 & 25 & 5 & 1 & 0 \\
\hline 10 & $\begin{array}{l}\text { Saya tidak suka update status dan } \\
\text { mengunggah foto di jejaring sosial. }\end{array}$ & 3 & 13 & 13 & 20 & 4 \\
\hline 11 & $\begin{array}{l}\text { Saya sering chatting melalui BBM, } \\
\text { WhatsApp, dan LINE di handphone. }\end{array}$ & 11 & 20 & 2 & 9 & 11 \\
\hline 12 & $\begin{array}{l}\text { Saat istirahat, hal pertama yang saya } \\
\text { lakukan adalah melihat handphone. }\end{array}$ & 16 & 17 & 5 & 10 & 5 \\
\hline 13 & $\begin{array}{l}\text { Hasil belajar saya meningkat setelah } \\
\text { memiliki handphone. }\end{array}$ & 3 & 13 & 16 & 18 & 3 \\
\hline
\end{tabular}




\begin{tabular}{|c|c|c|c|c|c|c|}
\hline No & Pernyataan & SS & $\mathrm{S}$ & $\mathrm{RR}$ & $\mathrm{TS}$ & STS \\
\hline 14 & $\begin{array}{l}\text { Konsentrasi belajar saya sering kali } \\
\text { terganggu dengan bunyi panggilan } \\
\text { (telepon, SMS, BBM, dll). }\end{array}$ & 15 & 27 & 3 & 7 & 1 \\
\hline 15 & $\begin{array}{l}\text { Hasil belajar saya menurun setelah } \\
\text { memiliki handphone. }\end{array}$ & 5 & 21 & 11 & 11 & 5 \\
\hline
\end{tabular}

Berdasarkan data di atas, dapat diketahui bahwa sebanyak 50 responden (95\%) memiliki handphone yang dapat digunakan untuk mengakses internet. Selain itu, 52 responden (98\%) mengakui bahwa kepemilikan handphone ini dapat memudahkan mereka dalam menambah wawasan belajar. Sebanyak 42 responden $(79,25 \%)$ juga mengakui bahwa mereka lebih mencari informasi tentang pelajaran dibandingkan bermain game di handphone.

Akan tetapi, mereka juga mengakui bahwa dengan kepemilikan handphone ini, mereka dapat memperbaharui status di Twitter dan Facebook (47 responden/88,68\%), mengobrol via BBM, WhatsApp, dan Line (31 responden/58,49\%), hingga hal pertama yang mereka lakukan ketika istirahat ialah mengecek handphone mereka (33 responden/62,27\%). Hal ini tentu saja berimbas pada konsentrasi belajar mereka. Sebanyak 42 responden $(79,25 \%)$ mengakui bahwa konsentrasi belajar mereka kerap terganggu akibat bunyi pemberitahuan dari handphone mereka. Akibatnya, hasil belajar mereka menjadi menurun. Hal tersebut diakui oleh 26 responden (49\%).

Berdasarkan hasil penelitian tersebut, dapat disimpulkan bahwa kepemilikan handphone ternyata tidak berbanding lurus dengan peningkatan hasil belajar. Meski sering kali peserta didik menggunakan handphone-nya sebagai media berselancar ke dunia maya untuk mencari informasi, namun nyatanya, penggunaan handphone itu juga tidak terlepas pada kegiatan mereka dalam hal mengunggah status di media sosial. Selain itu, mereka juga kerap menggunakan handphone sebagai media chatting di beberapa aplikasi. Pemberitahuan yang masuk ke handphone mereka, sebagai tanda respons atau balasan dari media sosial yang mereka gunakan, malah mengganggu konsentrasi belajar mereka. Hal inilah, yang kemudian mempengaruhi prestasi belajar mereka.

Selain kepemilikan handphone, juga diteliti terkait uang saku peserta didik. Berikut hasil penelitiannya:

Tabel 2. Pernyataan Mengenai Uang Saku Peserta Didik 


\begin{tabular}{|c|c|c|c|c|c|c|}
\hline No & Pernyataan & $\mathrm{SS}$ & $\mathrm{S}$ & $\mathrm{RR}$ & $\mathrm{TS}$ & STS \\
\hline 1 & $\begin{array}{l}\text { Saya sering menghabiskan uang saku } \\
\text { untuk membeli pulsa paket internet. }\end{array}$ & 9 & 23 & 6 & 12 & 3 \\
\hline 2 & $\begin{array}{l}\text { Saya sering meminta uang tambahan } \\
\text { untuk membeli pulsa paket internet. }\end{array}$ & 3 & 17 & 6 & 23 & 4 \\
\hline 3 & $\begin{array}{l}\text { Saya sering menyisihkan uang saku } \\
\text { untuk membeli pulsa paket internet. }\end{array}$ & 13 & 29 & 4 & 5 & 2 \\
\hline 4 & $\begin{array}{l}\text { Saya memilih pulsa paket internet yang } \\
\text { termurah untuk saya gunakan. }\end{array}$ & 20 & 28 & 3 & 1 & 1 \\
\hline 5 & $\begin{array}{l}\text { Saya memilih provider termurah karena } \\
\text { faktor iklan. }\end{array}$ & 1 & 19 & 23 & 8 & 2 \\
\hline 6 & $\begin{array}{l}\text { Saya membeli paket internet termurah } \\
\text { dari provider yang saya pakai. }\end{array}$ & 9 & 25 & 10 & 6 & 3 \\
\hline 7 & $\begin{array}{l}\text { Saya membeli pulsa paket internet } 2-3 \\
\text { kali dalam seminggu. }\end{array}$ & 5 & 11 & 9 & 20 & 8 \\
\hline 8 & $\begin{array}{l}\text { Saya memakai pulsa paket internet per } \\
\text { bulan. }\end{array}$ & 9 & 12 & 17 & 9 & 6 \\
\hline 9 & $\begin{array}{l}\text { Saya lebih memilih membeli pulsa paket } \\
\text { internet dibandingkan dengan membeli } \\
\text { makanan/jajan. }\end{array}$ & 1 & 5 & 20 & 15 & 12 \\
\hline 10 & $\begin{array}{l}\text { Saya sering begadang untuk } \\
\text { menggunakan bonus kuota internet yang } \\
\text { hanya mulai dari pukul 01.00-06.00 } \\
\text { WIB }\end{array}$ & 3 & 6 & 9 & 19 & 16 \\
\hline 11 & $\begin{array}{l}\text { Saya sering menggunakan fasilitas WiFi } \\
\text { di tempat umum untuk meminimalisasi } \\
\text { penggunaan kuota paket internet. }\end{array}$ & 11 & 19 & 14 & 6 & 3 \\
\hline 12 & $\begin{array}{l}\text { Saya menggunakan kuota internet lebih } \\
\text { kepada penggunaan media sosial } \\
\text { dibandingkan dengan game. }\end{array}$ & 12 & 24 & 9 & 6 & 2 \\
\hline 13 & $\begin{array}{l}\text { Saya sangat aktif berinteraksi di jejaring } \\
\text { sosial sehingga menghabiskan batas } \\
\text { maksimum kuota dan memaksa saya } \\
\text { untuk membeli pulsa menambah kuota. }\end{array}$ & 6 & 15 & 12 & 13 & 7 \\
\hline 14 & $\begin{array}{l}\text { Paket internet saya sering habis seketika } \\
\text { karena terambil oleh iklan game online } \\
\text { yang ada dalam handphone. }\end{array}$ & 7 & 14 & 8 & 13 & 11 \\
\hline 15 & $\begin{array}{l}\text { Saya memakai dua provider dalam } \\
\text { handphone. }\end{array}$ & 8 & 11 & 8 & 16 & 10 \\
\hline
\end{tabular}

Berdasarkan data di atas, dapat diketahui bahwa sebanyak 32 responden $(60 \%)$ sering menghabiskan uang saku untuk membeli pulsa paket internet. Selain itu, 27 responden (51\%) mengaku tidak meminta uang tambahan untuk membeli pulsa paket internet. Sebanyak 42 responden $(79,25 \%)$ juga mengakui bahwa mereka sering menyisihkan uang saku untuk membeli pulsa paket internet.

Akan tetapi, mereka juga mengakui bahwa dalam pembelian pulsa paket internet ini, mereka memilih pulsa paket internet yang termurah untuk mereka 
gunakan (48 responden/89\%). Selain itu, mereka juga sering menggunakan fasilitas WiFi di tempat umum untuk menghemat pemakaian kuota paket internet (30 responden/56\%). Sebanyak 36 responden (67\%) mengakui menggunakan kuota internet lebih kepada penggunaan media sosial dibandingkan untuk bermain game.

Berdasarkan hasil penelitian tersebut, dapat disimpulkan bahwa dalam pembelian pulsa paket internet, mereka sering kali menerapkan prinsip ekonomi dengan mengontrol pembelian pulsa paket internet. Meski mereka sering menghabiskan uang saku untuk pembelian pulsa paket internet, namun mereka mengaku tidak meminta uang tambahan. Mereka lebih memilih untuk menyisihkan uang saku mereka. Akibatnya, mereka cenderung untuk memilih membeli pulsa paket internet yang termurah. Mereka juga mengontrol pengeluaran mereka dalam pembelian pulsa ini dengan cara menghemat penggunaan kuota mereka. Hal ini terbukti dari pengakuan mereka yang lebih memilih menggunakan fasilitas WiFi di tempat umum, juga dengan hanya menggunakan kuota mereka untuk penggunaan media sosial dibandingkan untuk bermain game.

Selain itu, hasil instrumen pengaruh kepemilikan handphone terhadap uang saku peserta didik yang berupa data kuantitatif juga dapat diolah dengan menggunakan teknik statistik deskriptif yang terdiri data skor. Berdasarkan pengaruh kepemilikan handphone terhadap uang saku peserta didik.

Dari hasil perhitungan didapatkan persamaan regresi $\mathrm{Y}=\mathrm{a}+\mathrm{bx} \rightarrow \mathrm{Y}=$ $8,77+0,74 \mathrm{X}$. Berdasarkan persamaan tersebut dapat disimpulkan bahwa bentuk pengaruh penilaian terhadap kepemilikan handphone (variabel $\mathrm{X}$ ) dengan uang saku peserta didik (variabel Y) adalah linier dan signifikan. Persamaan regresi tersebut menunjukkan bahwa setiap kenaikan 1 (satu) skor penilaian terhadap kepemilikan handphone (variabel $\mathrm{X}$ ) dapat menyebabkan peningkatan uang saku peserta didik (variabel Y) sebesar 0,74. Skor pada konstanta 8,77.

Pengujian korelasi didapatkan hasil $\mathrm{r}$ sebesar 0,54. Hal ini menunjukkan bahwa antara kepemilikan handphone terhadap uang saku peserta didik mempunyai pengaruh yang cukup kuat. Artinya bahwa kepemilikan handphone akan berpengaruh terhadap uang saku peserta didik. 
Hasil pengujian koefisien determinasi sebesar 29,16\%. Hal ini menunjukkan bahwa tingkat pengaruh kepemilikan handphone terhadap peningkatan uang saku peserta didik sebesar 29,16\%, sisanya 70,84\% adalah pengaruh lainnya.

Hasil uji hipotesis nilai $t_{\text {hitung }}$ lebih besar jika dibandingkan dengan nilai $t_{\text {tabel }}(4,58>1,674)$ maka berarti $H_{1}$ diterima dan $H_{0}$ ditolak. Ini berarti terdapat korelasi atau pengaruh yang signifikan antara kepemilikan handphone terhadap uang saku peserta didik untuk pembelian pulsa paket internet di SMK Yamas Jakarta Timur.

\section{SIMPULAN}

Berdasarkan hasil penelitian, dapat disimpulkan bahwa kepemilikan handphone ternyata tidak berbanding lurus dengan peningkatan hasil belajar. Selain itu, dalam pembelian pulsa paket internet, peserta didik juga sering kali menerapkan prinsip ekonomi dengan mengontrol pembelian pulsa paket internet. Berdasarkan hasil uji regresi sederhana, didapatkan persamaan regresinya adalah $\mathrm{Y}=8,77+0,74 \mathrm{X}$. Artinya, setiap kenaikan 1 (satu) unit variabel X (kepemilikan handphone) akan berpengaruh terhadap variabel $\mathrm{Y}$ (uang saku peserta didik) sebesar 0,74 pada konstanta 8,77. Berdasarkan hasil uji koefisien korelasi hasil $r=$ 0,54 yang dapat diartikan bahwa terdapat pengaruh tingkat korelasi yang cukup kuat antara kepemilikan handphone (variabel $\mathrm{X}$ ) terhadap uang saku peserta didik (variabel Y). Berdasarkan koefisien determinan bahwa kontribusi kepemilikan handphone terhadap uang saku peserta didik sebesar 29,16\% dan sisanya sebesar $70,84 \%$ adalah kontribusi variabel-variabel lain yang tidak diteliti pada penelitian ini. Berdasarkan pengujian hipotesis di dapat nilai t_(hitung $)=4,58>\mathrm{t} \_(0,05$ $(53))=1,674$ maka $H_{0}$ ditolak. Jadi, ada pengaruh positif dan signifikan antara kepemilikan handphone terhadap uang saku peserta didik untuk pembelian pulsa paket internet di SMK Yamas Jakarta.

Kepemilikan handphone yang dimiliki oleh peserta didik di SMK Yamas Jakarta mempunyai pengaruh yang cukup kuat terhadap peningkatan uang saku peserta didik. Hal ini sesuai dengan hasil penelitian yang dilakukan, baik pada analisis regresi, koefisien korelasi (r), koefisien determinan (KD), maupun pengujian hipotesis yaitu $t_{\text {hitung }}>t_{\text {tabel. }}$ Untuk itu, peneliti menyarankan sebaiknya 
Research and Development Journal Of Education

Vol. 5 No. 1 Oktober 2018

ISSN 2406-9744

peserta didik mengurangi pemakaian handphone untuk hal-hal yang kurang produktif dan mendidik, karena handphone memberikan dampak kurang baik dan menurunkan kualitas belajar. Guru juga berperan penting dalam mengarahkan agar peserta didik tidak memiliki ketergantungan kepada handphone mereka. Bila perlu, guru harus memberikan sanksi tegas kepada peserta didik yang menggunakan handphone untuk hal-hal yang tidak berhubungan dengan kegiatan di kelas.

\section{DAFTAR PUSTAKA}

\section{Buku}

Arikunto, Suharsimi. 2010. Prosedur Penelitian. Jakarta: Rineka Cipta.

Darmawan, Deni dkk. 2006. Dasar Teknologi Informasi dan Komunikasi. Bandung: UPI Press.

Daryanto dan Setyobudi, Ismanto. 2014. Konsumen dan Pelayanan Prima. Yogyakarta: Gava Media.

Depdikbud 2003. Undang-Undang Republik Indonesia Nomor 20 Tahun 2003 Tentang Sistem Pendidikan Nasional. Jakarta: Aneka Ilmu.

Iqbal Hasan, Muhammad. 2003. Pokok-pokok Materi Statistik 2 (Statistik Inferensif). Jakarta: Bumi Aksara.

Kottler dan Keller. 2007. Manajemen Pemasaran Jilid 1. Jakarta: Macanan Jaya Cemerlang.

Limakrisna, Nandan dan Hary Susilo, Wilhelmus. 2012. Manajemen Pemasaran (Teori dan Aplikasi dalam Bisnis). Jakarta: Mitra Wacana Media.

Miarso, Yusufhadi. 2007. Menyemai benih teknologi pendidikan. Jakarta: Pustekom Diknas.

Mubarok, Mufti. 2012. Memprogram Anak Jadi Pengusaha. Surabaya: MUMTAZ Media. 
Research and Development Journal Of Education

Vol. 5 No. 1 Oktober 2018

ISSN 2406-9744

Mufid, Muhammad. 2005. Komunikasi dan Regulasi Penyiaran. Jakarta: Prenada Media Group.

N.H., Fairus. 2005. Teknologi Informasi dan Komunikasi. Jakarta: Ganeca Exact.

Nurudin. 2005. Sistem Komunikasi Indonesia. Jakarta: Raja Grafindo.

Permana, Budi. 2010. Jejaring Sosial. Jakarta: Elex Media Komputindo.

Shinta, Agustina. 2011. Manajemen Pemasaran. Malang: Universitas Brawijaya Press.

Sugiyono. 2010. Metode Penelitian Bisnis. Bandung: Alfabeta.

Tirtarahardja, Umar dan Sulo, La. 2005. Pengantar Pendidikan. Jakarta: Rineka Cipta.

Uchjana Effendy, Onong. 2004. Ilmu Komunikasi (Teori dan Praktek). Bandung: Remaja Rosdakarya.

\section{Jurnal}

Megawati, Yenli. (2006). Kualitas Pelayanan Terkait dengan Kepuasan Konsumen dalam Industri Jasa. Business \& Management Journal Bunda Mulia, Vol. 2 No. 2, 1-11. 